\title{
Sexual Maturity and Early Life History of the Mudskipper Scartelaos gigas (Pisces, Gobiidae): Implications for Conservation
}

\author{
Jin Koo Kim ${ }^{1 *}$, Hea-Ja Baek ${ }^{1}$, Jae-Won Kim ${ }^{2}$, Dae-Soo Chang ${ }^{3}$ and Joo-Il Kim ${ }^{4}$ \\ ${ }^{1}$ Department of Marine Biology, Pukyong National University, Busan 608-737, Korea \\ ${ }^{2}$ Department of Marine Science, Gangwon Province College, Gangneung 210-804, Korea \\ ${ }^{3}$ Subtropical Fisheries Research Center, NFRDI, Jeju 690-192, Korea \\ ${ }^{4}$ Southeast Sea Fisheries Research Institute, NFRDI, Tongyoung 650-943, Korea
}

\begin{abstract}
Scartelaos gigas is an amphibious mudskipper species that inhabits mud flats in Korea, China, and Taiwan. This fish is at risk of extinction because of its very restricted habitat and overexploitation. Information about this fish's reproductive characteristics is needed for species conservation. The sexual maturity and early life history of $S$. gigas were investigated through histological methods and direct observation of eggs in the wild, respectively. In total, 560 individuals of $S$. gigas were collected with the aid of fishermen from March 2003 to October 2003 at Jung-do Island, southwest Korea. Through microscopic observations of gonadal development, it was determined that $S$. gigas of both sexes were immature in April, but began to reach maturity in May, and were then fully mature by June, which was maintained until July. In August, some female fish developed early oocytes, but by September oocytes were observed to have degenerated and had been absorbed. Spawned eggs were elliptical and had an average size of $1.37 \mathrm{~mm}$ (long axis) by $0.69 \mathrm{~mm}$ (short axis). The newly hatched larvae (3.03 mm total length, TL) had an open mouth and anus, two melanophores near the anus, and one large melanophore between the 18th and 19th myomeres. The larvae (3.18 mm TL) showed absorption of the yolk and oil globule within 5 days after hatching and became prelarvae. This species should be considered vulnerable or conservation-dependent, and thus parental fish need to be protected from fishermen during the main spawning season (June).
\end{abstract}

Key words: Scartelaos gigas, Sexual maturity, Early life history, Conservation, Gobiidae.

\section{Introduction}

Scartelaos gigas (Perciformes, Gobiidae), a kind of mudskipper goby, is restricted to the mud flats of Korea, China, and Taiwan (Murdy, 1989; Lin et al., 1994; Randall and Lim, 2000; Park et al., 2008). In Taiwan, S. gigias is considered in danger of becoming extinct (Dr. Shao, personal communication). This fish may be at a high risk of extinction because of its very restricted habitat compared with Boleophthalmus pectinirostris (Park et al., 2008). Regarding habitat character- istics, Kim et al. (in preparation) documented that $S$. gigas prefers to live in mud flats with more than $99 \%$ mud, but $B$. pectinirostris prefers less than $95 \%$ mud; accordingly, the former shows a very restricted distribution. Additionally, habitat destruction by indiscreet coastal development by government and overexploitation by fishermen can hasten the extinction of these species (Park et al., 2008). Many studies have focused on the more widely distributed mudskipper, B. pectinirostris,
Open Access http://dx.doi.org/10.5657/FAS.2011.0403

This is an Open Access article distributed under the terms of the Creative Commons Attribution Non-Commercial License (http://creativecommons. org/licenses/by-nc/3.0/) which permits unrestricted non-commercial use, distribution, and reproduction in any medium, provided the original work is properly cited. pISSN: 2234-1749 eISSN: 2234-1757
Received 24 August 2011; Revised 1 November 2011; Accepted 7 November 2011

*Corresponding Author

E-mail: taengko@hanmail.net 
including a series of studies on its aquaculture in Japan during the late 1980s (Koga et al., 1989a, 1989b, 1989c; Noda and Koga, 1990a, 1990b; Yuzuriha and Koga, 1990; Yuzuriha et al., 1990; Koga and Baba, 1991; Washio et al., 1991). There have also been many reports on B. pectinirostris in Korea, including studies of its oocyte maturation (Chung et al., 1989), sexual maturation (Chung et al., 1991), age and growth (Jeong et al., 2004), growth of age-0 fish (Kim and Jeong, 2007), and habitat and spawning (Jeong et al., 2010). However, there is no reported study of $S$. gigas except a single study on its age and growth (Park et al., 2008). This dearth of studies on S. gigas is probably attributable to its very limited habitat compared with that of $B$. pectinirostris, as mentioned above. However, $S$. gigas and $B$. pectinirostris are both widely consumed by humans, and thus the populations of both these fishes may be decreased through overfishing.

From the viewpoint of species conservation and fisheries management, the growth and reproductive ecology of $S$. gigas are of primary interest. Thus, the present study investigated the sexual maturity and early life history of $S$. gigas in Korea to gain valuable information for species conservation and management.

\section{Materials and Methods}

\section{Sample collection and measurements}

In total, 50-100 individuals of $S$. gigas were collected biweekly by the aid of fishermen using a fishing pole and hook from March 2003 to October 2003 at Jung-do Island mud flats in southwestern Korea (Table 1, Fig. 1). The fishes' total length $(\mathrm{mm})$ and body weight $(\mathrm{g})$ were measured, and they were dissected to determine the sex ratio (female / pooled) and sexual maturity. The $\chi^{2}$-test was used to detect differences in the sex ratio (Minitab Program).

\section{Histological examination}

The extracted gonads were fixed with Bouin's solution, then embedded in paraffin, sectioned at a thickness of 3-5 $\mu \mathrm{m}$, and stained with Mayer's hematoxylin and $0.5 \%$ eo$\sin (\mathrm{H} \& \mathrm{E})$. Assessment of the developmental stage of the gonads and their relative stages was based on that of Yasutake and Wales (1983). The gonads were observed under an optical microscope, and gonadal development was classified into five phases: immature, mature, ripe, spent, and degenerated.

\section{Spawning characteristics and early life history}

To examine the habitat structure of $S$. gigas, we mixed Komaica solution (PT380; Geumgang-koryo Co., Korea) and hardener and used it to fill a burrow where $S$. gigas were known to spawn. After 2 to $3 \mathrm{~h}$, the mud around the burrow

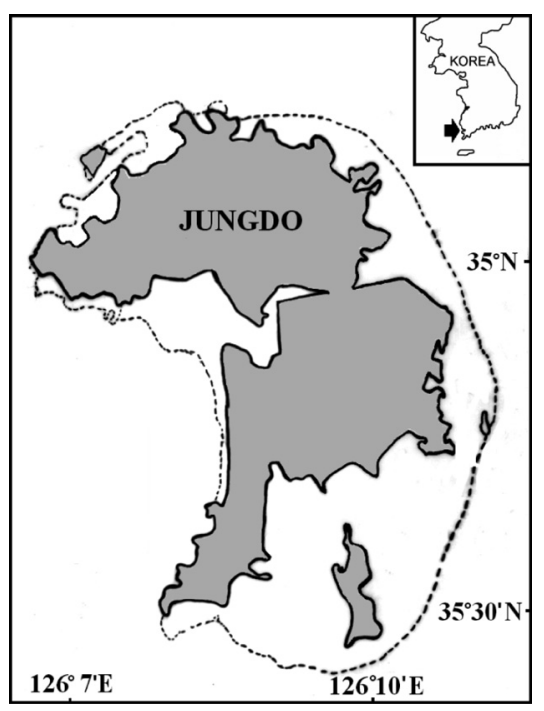

Fig. 1. Sampling area of Scartelaos gigas. Dotted line is mud flat area..

was excavated, following the method of Koga and Noda (1992). Egg masses protected by a parent in the spawning burrow were collected with the aid of fishermen and transferred to the laboratory. Egg diameter and larval size were measured using the Image Pro Plus program (version 4.5; Cybernetics, USA) with a stereomicroscope (SZH10, Olympus, Japan). The shapes of embryos in the eggs and larvae after hatching were observed and photographed using a digital camera attached to the stereomicroscope. The hatched larvae were reared in a small water tank at a water temperature of $20^{\circ} \mathrm{C}$ for 5 days. The terminology used for eggs and larvae followed that of Russell (1976) and Okiyama (1988).

Table 1. Collection data of Scartelaos gigas from Jung-do Island, Korea in 2003

\begin{tabular}{lccccc}
\hline \multirow{2}{*}{$\begin{array}{c}\text { Date } \\
\text { Month/day }\end{array}$} & \multicolumn{2}{c}{ No. of specimens } & & \multicolumn{2}{c}{ Total length $(\mathbf{m m})$} \\
\cline { 2 - 3 } \cline { 6 - 7 } & Female & Male & & Female & Male \\
\hline March/23 & 17 & 13 & & $134.5-201.2$ & $144.3-191.6$ \\
April/17 & 22 & 18 & & $127.1-186.1$ & $132.5-180.6$ \\
April/30 & 18 & 18 & & $118.8-182.4$ & $124.8-180.4$ \\
May/12 & 32 & 18 & & $149.0-195.5$ & $162.1-190.1$ \\
May/28 & 24 & 26 & & $132.4-192.0$ & $133.6-189.0$ \\
June/10 & 28 & 31 & & $134.4-189.5$ & $136.8-186.6$ \\
June/25 & 35 & 14 & & $137.4-192.5$ & $125.6-192.1$ \\
July/7 & 6 & 4 & & $149.4-188.2$ & $141.9-188.8$ \\
July/15 & 18 & 21 & & $116.4-181.9$ & $115.8-188.8$ \\
July31 & 35 & 18 & & $131.2-186.1$ & $111.6-170.6$ \\
August/13 & 26 & 26 & & $142.4-186.1$ & $141.4-185.9$ \\
August/26 & 16 & 4 & & $135.1-193.5$ & $128.1-151.4$ \\
September/9 & 7 & 13 & & $152.9-182.1$ & $124.7-180.9$ \\
Septermber/21 & 21 & 31 & & $139.4-192.2$ & $130.4-194.1$ \\
September/28 & 21 & 13 & & $129.9-179.1$ & $131.3-192.8$ \\
October/15 & 20 & 30 & & $158.9-188.0$ & $168.0-186.5$ \\
October/29 & 14 & 34 & & $138.5-181.2$ & $136.9-186.1$ \\
\hline
\end{tabular}




\section{Results}

\section{Sexual maturity}

The biweekly variations in the gonodosomatic index (GSI) of S. gigas are shown in Fig. 2. GSI in females was low until May 12, but increased abruptly on May 28, reached a maximum during June 10 to July 15 , and decreased suddenly on July 31 . The mean values of GSI in females were greater than 6.0 between May 28 and July 15. Similarly, in males, GSI was low until May 12, but increased rapidly and reached a maximum on May 28 , which was maintained until July 7 , after which GSI decreased gradually. The mean values of GSI in males were greater than 0.1 between May 28 and July 7 (Fig. 2).

The $S$. gigas testis is typically an elongated paired organ with a threadlike shape found in the dorsal part of the body cavity and attached to the air bladder anteriorly and to the urogenital pore posteriorly. Spermatogonia were found in the testicular tubule of an 18.1-cm total length (TL) specimen collected in April 2003 (Fig 3A). Germ cells were observed in the testicular cyst, which was densely stained with
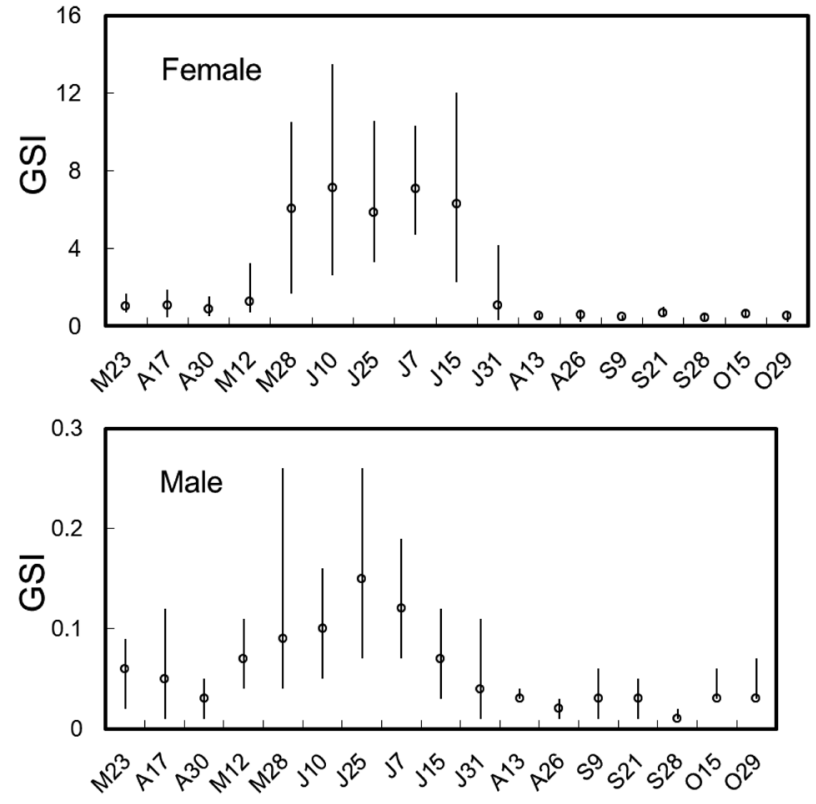

Fig. 2. Monthly change in gonadosomatic index (GSI) of Scartelaos gigas. Open circles indicate mean and bars indicate minimum and maximum.

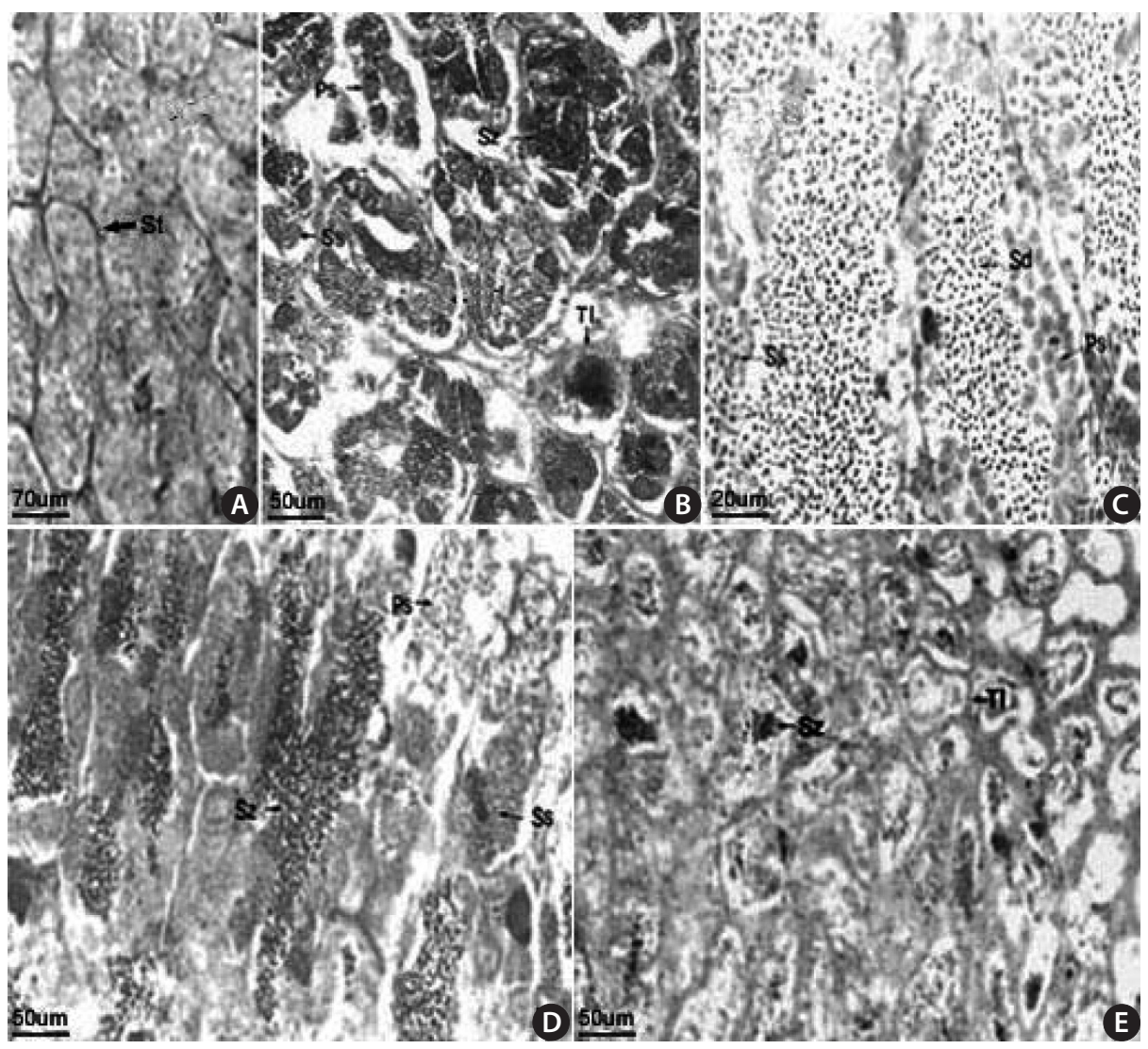

Fig. 3. Histological sections showing developmental stages of male Scartelaos gigas.(A) Immature stage, 30, April, (B) Mature stage, 10, June, (C) Ripe stage, 25, June, (D) Just after spent stage, 7, July, (E) Spent and degenerative stage, 21, September. Ps, primary spermatocytes; Sd, spermatids; Ss, secondary spermatocytes; Sl, seminiferus lobuli; Sz, spermatozoon; $\mathrm{Tl}$, testicular lobule. 

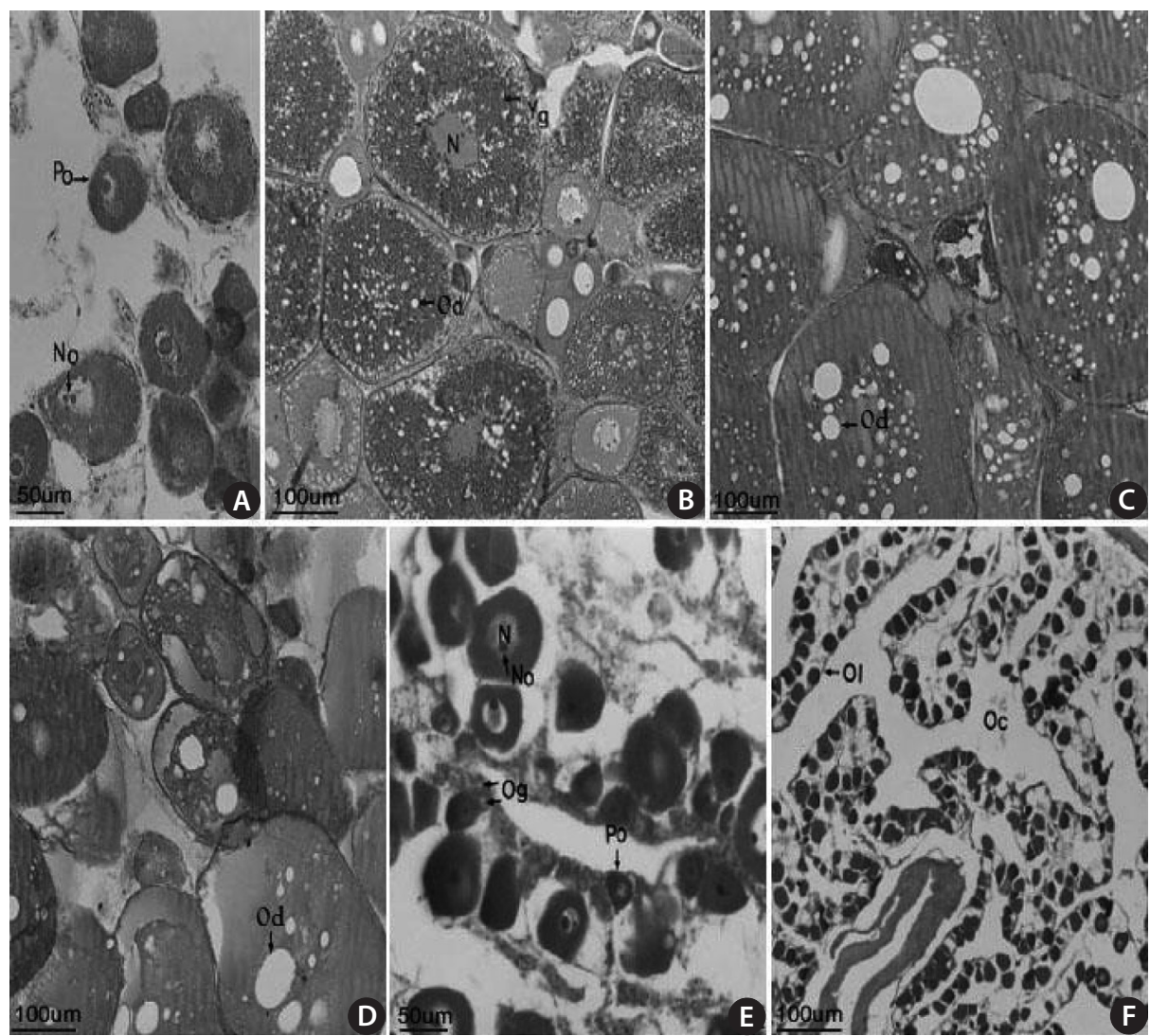

Fig. 4. Histological sections showing developmental stages of female Scartelaos gigas.(A) Immature stage, 30, April, (B) Mature stage, 25, June, (C) Ripe stage, 10, June, (D) Just after spent stage, 15, July, (E, F) Degenerative and resting stage, 13, August (E) and 21, September (F). N, nucleus; No, nucleolus; Oc, ovarian cavity; Od, oil droplet; Og, oogonia; Ol, ovarian lamella; Oo, oocytes; Po, primary oocytes; Yg, yolk globule.

hematoxylin, and spermatozoa developed from spermatids were observed in an 18.0-cm TL specimen, collected in June 2003 (Fig. 3B). Spermatocytes, spermatids, and spermatozoon were observed in a $12.3-\mathrm{cm}$ TL specimen collected in June 2003 (Fig. 3C). We confirmed that mature spermatozoa exit through the testicular tubule and the spermatic duct, as observed in a 14.2-cm TL specimen collected in July 2003. Many sperm were visible in the narrow lumens (Fig. 3D). The number of mature spermatozoa aggregated densely in the testicular cyst was decreased due to release of sperm, and the lobular lumen became too weak to maintain a vacuolar structure. A specimen of $18.4 \mathrm{~cm}$ TL collected in September 2003 had thicker epithelial tissue in the testicular tubule (Fig. $3 \mathrm{E})$. These results led us to conclude that the gonadal tissue of male S. gigas started to develop in May and that sperm were released from early June to mid-July.

The female gonads have a saccular shape and are located on the left and right sides of the posterior abdominal cavity. Early oocytes of approximately $50-150 \mu \mathrm{m}$ in diameter and 1-3 nucleoli were seen in the nucleoplasm of a $18.2-\mathrm{cm}$ TL female specimen collected in April 2003 (Fig 4A). An oocyte of 200-380 $\mu \mathrm{m}$ in diameter and containing a yolk globule and oil droplets only in the cortical layer of the cytoplasm, and mature eggs containing a fused yolk granule and without a visible nucleus were observed in a $13.7-\mathrm{cm}$ TL specimen collected in June 2003 (Fig. 4B). Mature oocytes of 200-400 $\mu \mathrm{m}$ in diameter with a homogeneous appearance were found in a 17.1-cm TL specimen collected in June 2003 (Fig. 4C). Many oil droplets were seen in 150-370 $\mu \mathrm{m}$ oocytes in a 13.7-cm TL specimen collected in July 2003 (Fig. 4D). Oocytes and oogonia were seen along with ovarian lamellae in a 16.9-cm TL specimen collected in August 2003 (Fig. 4E). No mature eggs, but 20-30 $\mu \mathrm{m}$ resting early oocytes were observed in a 19.2-cm TL specimen collected in September 2003 (Fig. 4F). These results suggest that the gonadal tissue of female $S$. gigas is ripe from June until mid-July.

The mean sex ratio was 53:47 (female:male); in particular, the ratio of males was significantly higher in October $(P=0.006)$ (Fig. 5), suggesting that the males feed more actively than females just before hibernation. The smallest female specimen containing mature gonads had a TL of 11.6 $\mathrm{cm}$, suggesting that females of at least $11 \mathrm{~cm} \mathrm{TL}$ are able to spawn. 


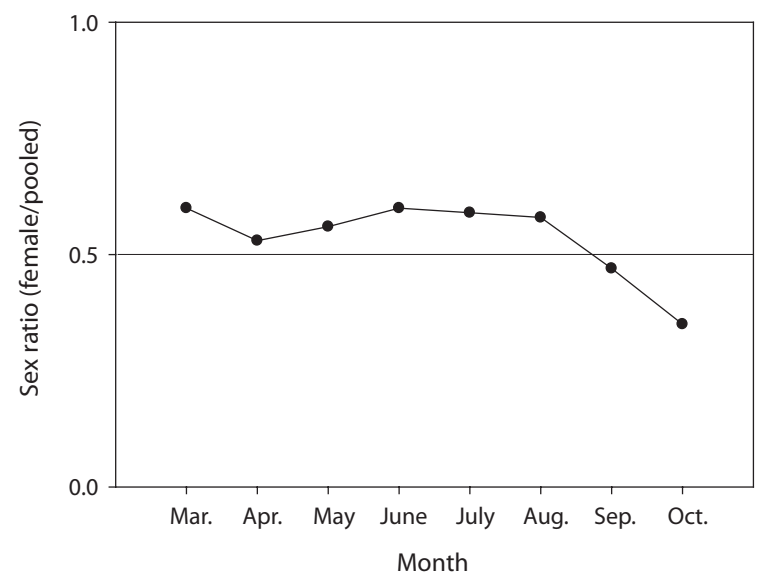

Fig. 5. Monthly change of sex ratio (female/pooled) of Scartelaos gigas.

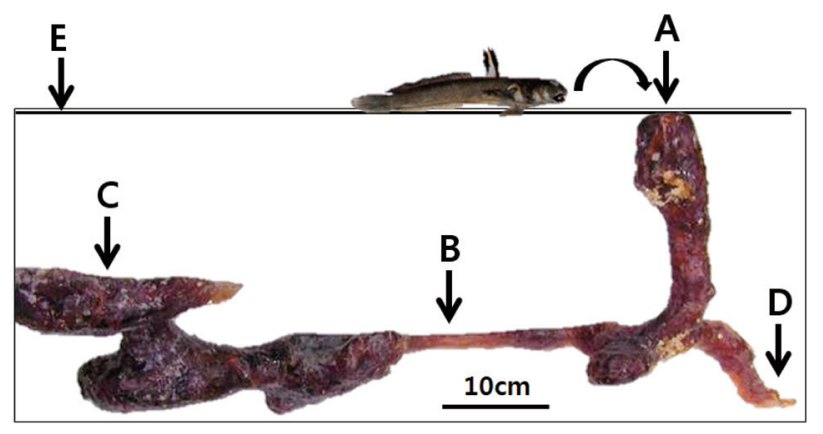

Fig. 6. Habitat cave of Scartelaos gigas. (A) Entrance, (B) Real passage, (C) Spawning cave, (D) Camouflage passage, (E) Mud surface. Egg mass of $S$. gigas was found in the upper layer of spawning cave along with one male protecting egg mass. Sometimes both one male and one female were found in the spawning cave during spawning season. Fishermen obstructed escape of $S$. gigas by stepping on real passage, then catched $S$. gigas through entrance by hand.

\section{Early life history}

One male specimen was found protecting eggs in the spawning burrow. The spawning burrow was oval and $20-25 \mathrm{~cm}$ in length, allowing air to exit the burrow (Fig. 6). The eggs adhered to the upper surface of the spawning burrow, attached by numerous fine filaments (Fig. 7A and 7B).

The spawned eggs had an elliptical shape, with a long axis of $1.23-1.48 \mathrm{~mm}(1.37 \pm 0.07 \mathrm{~mm}, n=17)$ and a short axis $0.67-0.71 \mathrm{~mm}(0.69 \pm 0.02 \mathrm{~mm}, n=17)$; thus, the long axis was approximately two times longer than the short axis. There were no melanophores in embryos just after collection, and one large oil globule and one small oil globule were observed (Fig. 7A).

Hatched larvae had a TL of 2.58-3.24 mm (mean, 3.03; $n$ $=12$ ) and their preanal length was about $45.7 \%$ of TL. The mouth and anus were open and an air bladder and a large egg
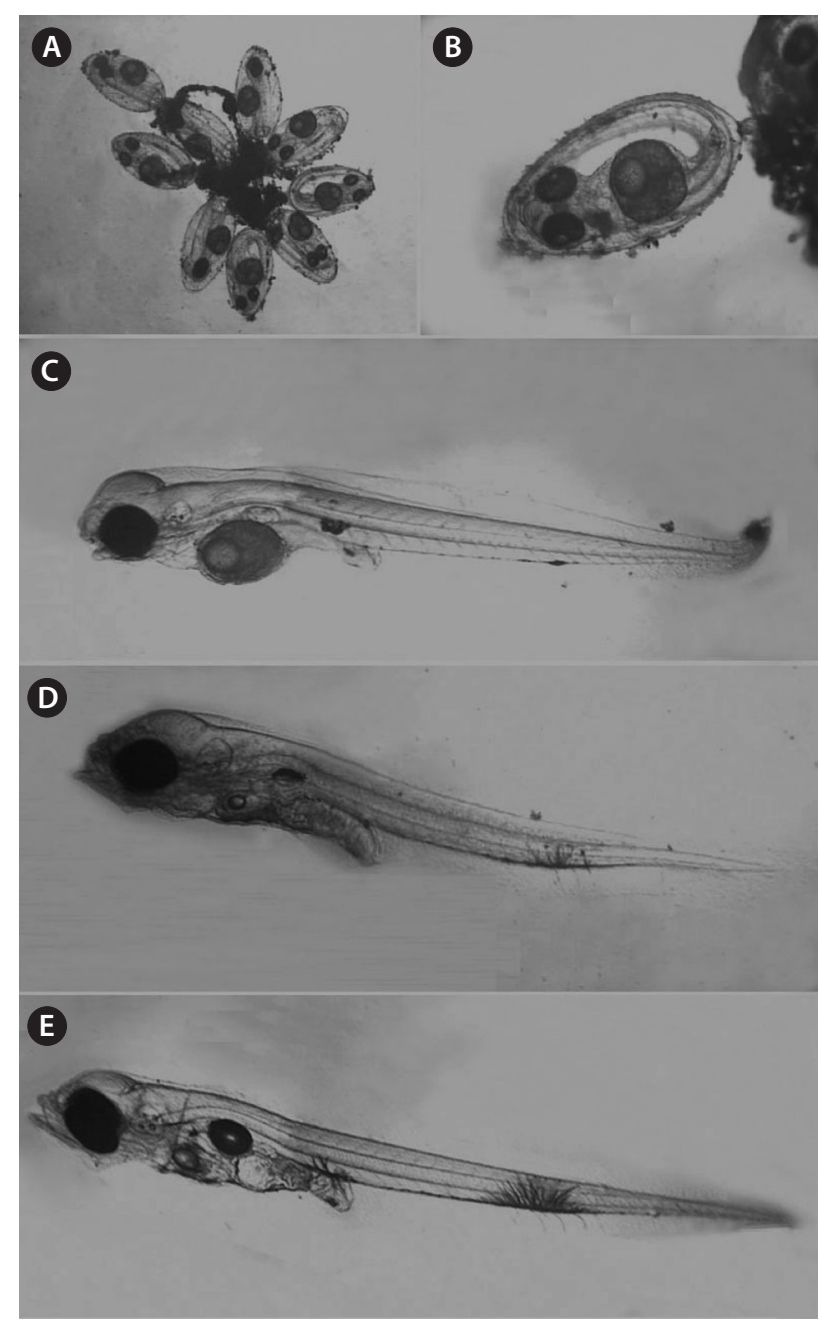

Fig. 7. Eggs and larval development of Scartelaos gigas. (A) Egg mass, (B) Embryonic stage, (C) Just-hatched larva, (D) Three days larva after hatching, (E) Five days larva after hatching.

yolk were observed. The oil globule was located in the anterior portion of the yolk. There was one melanophore on both the dorsal and ventral portions of the anus and there was one large branch-shaped melanophore on the ventral contour between the $18^{\text {th }}$ and $19^{\text {th }}$ myomeres (Fig. 7B). Three days after hatching, larvae had a TL of 3.05-3.26 mm (mean, $3.17 \mathrm{~mm} ; n$ $=9$ ) and the preanal length was $45.9 \%$ of the TL. The melanophore on the ventral contour of the mid-tail was large, and new melanophores were found on the peritoneum (Fig. 7C). At 5 days after hatching, larvae had a TL of 3.13-3.23 mm (mean, $3.18 \mathrm{~mm} ; n=7$ ) and the preanal length was $45.4 \%$ of the TL, similar to that at 3 days after hatching. The egg yolk was completely absorbed and only a small oil globule remained. Three or four melanophores were newly visible on the ventral abdomen (Fig. 7D). The amount of egg yolk declined rapidly over time and it had completely disappeared by the fifth day after hatching. However, the oil globule declined in size relatively 
slowly and could still be seen on the fifth day after hatching (Fig. 7E). These results suggest that $S$. gigas may switch from internal to external nutrition 4-5 days after hatching.

\section{Discussion}

\section{Sexual maturity}

Testicular structure in teleosts can be classified into two types: tubular and lobular, depending on the pattern of spermatogenesis (Billard et al., 1982). The testis of S. gigas are tubular, as are those of the blue-spotted mud hopper B. pectinirostris (Chung et al., 1991), the naked-headed goby $\mathrm{Fa}$ vonigobius gymnauchen (Lee et al., 2000), and the gluttonous goby Chasmichthys gulosus (Kim et al., 2004).

Teleost ovaries can be divided into three types based on the pattern of oocyte development: synchronous, group synchronous, and asynchronous (Nagahama, 1983). Oocyte development in S. gigas is synchronous, as determined by the GSI and histology.

The GSI was highest in May for B. pectinirostris (Jeong et al., 2004), but between June and mid-July for S. gigas (this study), demonstrating that the spawning season of $S$. gigas occurs later than that of $B$. pectinirostris. Similarly, the gonadal tissue of female $S$. gigas was in the ripe stage between June and mid-July. Our histological findings were consistent with the GSI findings.

Reports on B. pectinirostris spawning have been contradictory, with some studies concluding that this species spawns once a year (Zhang et al., 1989) and others suggesting that it spawns several times a year (Hoda, 1986; Chung et al., 1991; Washio et al., 1993). Washio et al. (1993) found that B. pectinirostris ovaries remained full of eggs even after spawning, and that fish were seen in the resting state only at the end of the spawning season, leading them to conclude that $B$. pectinirostris spawns several times during a spawning season. Kim and Jeong (2007) suggested that B. pectinirostris may spawn several times, based on a TL frequency distribution analysis of age-0 fish. However, our gonadal histology of $S$. gigas yielded similar results to those of Zhang et al. (1989), suggesting that $S$. gigas spawn once a year.

Boleophthalmus pectinirostris and S. gigas inhabit similar mud flat environments. Environmental factors are known to play an important role in regulating the reproductive cycles of teleosts (Lam, 1983). Successful reproduction entails the production of offspring when physical and biotic conditions are most likely to promote their survival (Miller, 1984). Scartelaos gigas exhibits distinct seasonality in its reproductive ability, as evidenced by marked cyclic changes in GSI and gonadal histology. It appears that these physiological changes are closely related to environmental changes in temperature, photoperiod, or availability of food.

\section{Early life history}

The elliptical-shaped eggs of S. gigas adhere to one another using many fine filaments, as is characteristic of most goby species. The function of the sperm-duct glands requires further study, but nest preparation by male gobies often entails rubbing the abdomen and urogenital papilla over a cleaned surface prior to egg deposition (Miller, 1984). The egg size of B. pectinirostris from the Gangjin mud flat is $1.23-1.44 \mathrm{~mm}$ (long axis) by 0.65-0.77 mm (short axis) (Jeong et al., 2010), similar to that of $S$. gigas $(1.23-1.48 \mathrm{~mm}$ by $0.67-0.71 \mathrm{~mm})$. The eggs were attached to the upper surface of the spawning burrow, in which only one male protected eggs. We newly found that air exists in the spawning burrow (see Fig. 7C) and may supply enough oxygen to the eggs. Mudskippers have been known to dig a Y-form burrow usually, but an L-form burrow during the spawning season (Ryu et al., 1995), consistent with our findings (Fig. 6). According to Koga and Noda (1992), B. pectinirostris usually dig a complex and very long burrow (its TL can reach $534 \mathrm{~cm}$ horizontally) but dig a simple and deep burrow vertically during hibernation.

The number of eggs produced is an indicator of species productivity. Studies have found 5,000-20,000 B. pectinirostris eggs per fish (Ryu et al., 1995) and 1,362-18,368 S. gigas eggs per fish (Park et al., 2008). It is believed that this kind of fish usually spawns fewer than 20,000 eggs. The TL of $B$. pectinirostris hatched larvae has been measured as 3.0-3.4 mm (Ryu et al., 1995) and 3.1-3.3 mm (Okiyama, 1988), similar to that of S. gigas larvae (2.58-3.24 mm). Boleophthalmus pectinirostris showed many small oil globules early in egg development, and these decreased significantly as the embryo developed (Ryu et al., 1995). Scartelaos gigas embryos contained two oil globules just prior to hatching, demonstrating that the number and size of oil globules change during egg development. A single oil globule was visible in S. gigas larvae, as seen in B. pectinirostris larvae (Ryu et al., 1995).

The melanophore is an important characteristic for identification of species during the larval stage (Russell, 1976; Kendall et al., 1984). Scartelaos gigas had one large melanophore on the ventral contour of the mid-tail from hatching until it reached $3.26 \mathrm{~mm}$ total length ( $3.13 \mathrm{~mm}$ notochord length). No melanophore was observed in the mid-tail region of $B$. pectinirostris at 3.1-3.3 mm (Okiyama, 1988). Accordingly, the melanophore is an important characteristic in distinguishing the two species before notochord flexion. The spawning ecology of $S$. gigas has not been studied before, and our new findings may be useful in the conservation and management of this species.

\section{Implications for conservation of S. gigas}

Ryu et al. (1995) studied the distribution of B. pectinirostris at 17 sites on the west and south coasts of Korea, and suggested that this fish is no longer found at Boryeong and Chungnam 
due to reclamation. We found that the distribution density of $S$. gigas was relatively high in mud flats in the southwest of Korea, but few were found in southern Korea. It is thought that the habitat of $S$. gigas is highly restricted compared with that of $B$. pectinirostris, resulting from differences in habitat preference between the two species. Scartelaos gigas prefer high mud areas (mud $>99 \%$ ) compared with B. pectinirostris ( $\operatorname{mud}>91 \%$ ) (Kim et al., in preparation). Additionally, juveniles or young fish of $S$. gigas were not collected in the wild; however, many young $B$. pectinirostris were collected very readily in the wild (Ryu et al., 1995; Kim and Jeong, 2007), suggesting the possibility of potential population collapse of $S$. gigas. Thus, the species should be considered a vulnerable or conservation-dependent species. In particular, parental fish need to be protected during the main spawning season (June) to preserve $S$. gigas eggs.

\section{Acknowledgments}

We are grateful to anonymous reviewers for their valuable comments and advice. This work was supported by the Pukyong National University and National Fisheries Research and Development Institute (contribution number: RP-2010FR-027).

\section{References}

Billard R, Fostier A, Weil C and Breton B. 1982. Endocrine control of spermatogenesis in teleost fish. Can J Fish Aquat Sci 39, 65-79.

Chung EY, Ryu BS and Kim JR. 1989. A study on the process of the ovarian maturation of the blue-spotted mud hopper, Boleophthalmus pectinirostris (Linnaeus). J Mar Dev Res Kunsan Nat'l Univ 1, 19-36.

Chung EY, Ah CM and Lee TY. 1991. Sexual maturation of the bluespotted mud hopper, Boleophthalmus pectinirostris (Linnaeus). J Korean Fish Soc 24, 167-176.

Hoda SMS. 1986. Maturation and fecundity of the mudskipper Boleophthalmus dussumieri Cuv. \& Val. from the Karachi coast. Bull Nat'1 Inst Oceanography 19, 73-78.

Jeong SJ, Han KH, Kim JK and Sim DS. 2004. Age and growth of the blue spot mudskipper (Boleophthalmus pectinirostris) in the mud flat of southwestern Korea. J Korean Fish Soc 37, 44-50.

Jeong SJ, Lee SH, Hwang JH, Yeon IH, Kim HJ, Lee JH and Han KH. 2010. Habitat and spawning of the blue mudskipper, Boleophthalmus pectinirostris distributed in the Kangjin Bay. Bull Fish Sci Inst Chonnam Nat'1 Univ 18, 92-97.

Kendall AW, Ahlstrom EH and Moser HG. 1984. Early life history stages of fishes and their characters. In: Ontogeny and Systematics of Fishes. Special Publication No. 1. Moser HG, ed. American Society of Ichthyologists and Herpetologists, Lawrence, KS, US, pp. 11-22.

Kim JK and Jeong SJ. 2007. Growth estimation of 0 -aged blue spot mudskipper Boleophthalmus pectinirostris using length frequency data. J Korean Fish Soc 40, 50-52.

Kim SY, Park CB, Kang JW, Choi YC, Rho S, Bawk HJ, Kim HB and Lee YD. 2004. Gonadal development and reproductive cycle of gluttonous goby Chasmichthys gulosus (Guichenot). Korean J Ichthyol 16, 216-270.

Koga H and Baba H. 1991. Appearance and distribution of mudskipper's larvae and juveniles. Bull Res Inst Shallow Sea Tideland 5, 45-49.

Koga H and Noda S. 1992. Seasonal change of the burrows' form of mudskipper. Bull Saga Prefect Ariake Fish Exp Stn 14, 81-84

Koga H, Noda S, Noguchi T and Aoto I. 1989a. Studies on artificial propagation of mud skipper Boleophthalmus pectinirostris (Linnaeus): III. Hatching and larval rearing. Bull Saga Prefect Ariake Fish Exp Stn 11, 17-28.

Koga H, Noda S, Noguchi T and Aoto I. 1989b. Studies on artificial propagation of mud skipper Boleophthalmus pectinirostris (Linnaeus): I. Rearing of adult mud skipper. Bull Saga Prefect Ariake Fish Exp Stn 11, 1-7.

Koga H, Noguchi T and Kinoshita K. 1989c. Studies on artificial propagation of mud skipper Boleophthalmus pectinirostris (Linnaeus): II. Collecting eggs by artificial spawning nest and spawning conditions. Bull Saga Prefect Ariake Fish Exp Stn 11, 9-16.

Lam TJ. 1983. Environmental influences on gonadal activity in fish. In: Fish Physiology, V. 9B. Hoar WS, Randall DJ and Donaldson EM, eds. Academic Press, New York, US, pp. 65-116.

Lee JS, Kim JW, Kang JC, Shin YK and Chin P. 2000. Reproductive cycle and gonadal development of the naked-headed goby, Favonigobius gymnauchen (Teleostei: Gobiidae). J Korean Fish Soc 33, 219-224.

Lin PL, Shao KT and Chen JP. 1994. Five new records of coastal fishes from western Taiwan. Zool Stud 33, 174-176.

Miller PJ. 1984. The ecology of gobioid fishes. In: Fish Reproduction: Strategies and Tactics. Potts GW and Wootton RJ, eds. Academic Press, New York, US, pp. 118-153.

Murdy EO. 1989. A taxonomic revision and cladistic analysis of the Oxudercine gobies (Gobiidae: Oxudercinae). Rec Aust Mus Suppl 11, 1-93.

Nagahama, Y. 1983. The functional morphology of teleost gonads. In: Fish Physiology. Vol 9. Hoar WS, Randall DJ and Donaldson EM, eds. Academic Press, New York, US, pp. 223-275.

Noda S and Koga H. 1990a. Studies on artificial propagation of mud skipper Boleophthalmus pectinirostris (Linnaeus) : IV. Feed of young fishes. Bull Saga Prefect Ariake Fish Exp Stn 12, 1-6.

Noda S and Koga H. 1990b. Studies on artificial propagation of mud skipper Boleophthalmus pectinirostris (Linnaeus) : V. Rearing young fishes in winter. Bull Saga Prefect Ariake Fish Exp Stn 12, 7-13.

Okiyama M. 1988. An Atlas of the Early Stage Fishes in Japan. Tokai Univ Press, Tokyo, JP.

Park KD, Kim JK, Chang DS, Kim JI and Oh CW. 2008. Age and growth of the mudskipper, Scartelaos gigas (Perciformes, Gobiidae) from Korea. Anim Cells Syst 12, 305-311.

Randall JE and Lim KKP. 2000. A checklist of the fishes of the South 
China Sea. Raffles Bull Zool Suppl (8), 569-667.

Russell FS. 1976. The Eggs and Planktonic Stages of British Marine Fishes. Academic Press, London, GB.

Ryu BS, Kim IS and Choi Y. 1995. Ecology and life history of Boleophthalmus pectinirostris in Korea. J Korean Fish Soc 28, 316-324.

Washio M, Tsutsui M and Takita T. 1991. Age and growth of the mudskipper Boleophthalmus pectinirostris distributed in the mud flat of Midori river, Kumamoto Prefecture. Nippon Suisan Gakkaishi $57,637-644$.

Washio M, Komiya S and Takita T. 1993. Maturation of the mudskipper Boleophthalmus pectinirostris distributed in the mud flats of the Midori river, Kumamoto Prefecture. Nippon Suisan Gakkaishi 59, 575-580.

Yasutake WT and Wales JH. 1983. Microscopic Anatomy of Salmonids:
An Atlas. United States, Department of the Interior, Fish and Wildlife Service, Washington, DC, US.

Yuzuriha M and Koga H. 1990. Ecological study of mud skipper Boleophthalmus pectinirostris (Linnaeus): III. Appearance and distribution of larvae and juveniles. Bull Saga Prefect Ariake Fish Exp Stn 12, 15-20.

Yuzuriha M, Koga H, Yoshimoto M and Baba H. 1990. Ecological study of mud skipper Boleophthalmus pectinirostris (Linnaeus): IV. Ecology of young fish. Bull Saga Prefect Ariake Fish Exp Stn 12, 21-27.

Zhang QY, Hong WS, Dai QN, Zhang J, Cai YY and Huang JL. 1989. Studies on induced ovulation, embryonic development and larval rearing of the mudskipper (Boleophthalmus pectinirostris). Aquaculture $83,375-385$. 